\title{
Temporal changes in the biochemical composition and nutritional value of the particulate organic matter available to surface deposit-feeders: a two year study
}

\author{
Antoine Grémare*, Jean Michel Amouroux, François Charles, Alain Dinet, \\ Catherine Riaux-Gobin, Julia Baudart, Laurence Medernach, Jean Yves Bodiou, \\ Gilles Vétion, Jean Charles Colomines, Philippe Albert
}

Laboratoire Arago, Université Pierre et Marie Curie, URA CNRS no. 2071, BP no. 44, F-66650 Banyuls-sur-Mer, France

\begin{abstract}
Gross sedimentation rates (GSR) were monitored together with the main characteristics of the collected matenal (i.e. organic content, C, N, total proteins, lipids, carbohydrates, available proteins and amino acids) over a 2 yr cycle at a shallow station $(18 \mathrm{~m})$ of the bay of Banyuls, France. In addition. sediment pigment concentrations and meiofaunal densities were recorded monthly during a 1 yr period. GSR ranged between 0.6 and $317.8 \mathrm{~g} \mathrm{DW} \mathrm{m}^{-2} \mathrm{~d}^{-1}$ Sprung and summer were characternzed by relatively low and constant GSR whereas fall and winter were characterized by relatively high and highly variable GSR. There was a negative relationship between GSR and the organic content of material collected within the sediment traps, suggesting the importance of resuspension in controlling GSR Growth rates of the deposit-feeding bivalve Abra ovata fed sediment trap material collected on 6 sampling dates were also measured. Significant changes in important nutrient components (e.g. available proteins) of sedimenting materials from these different sampling dates correlated with growth differences and confirmed the existence of temporal changes in the quality of the material collected in the sediment traps. The highest growth rate was obtained for the material collected during May 1993. which coincided with maximal meiofauna densities and maximal pigment concentrations at the surface of the sediment. The best description of growth was obtained when using available proteins and total lipids as the independent variables of simple linear regression models. This supports the use of these parameters as descriptors of food quality. The consequences of our results on the parameterization of changes in food quality within models of continental shelf food webs are discussed. It is suggested that such changes should be simulated through control functions based on available protein contents.
\end{abstract}

KEY WORDS: Particulate organic matter · Qualıty - Temporal changes - Available proteins

\section{INTRODUCTION}

Recent models of benthic trophic networks (Pace et al. 1984, Chardy 1987, Chardy \& Dauvin 1992) are based on global descriptors of organic matter, which cannot account for temporal changes in the quality of particulate organic matter (POM). This drawback is especially important in the case of coastal benthic eco-

•E-mail: gremare@arago.univ-perp.fr systems, which are fueled by very heterogeneous food sources, because (1) the different components of the POM pool are of different nutritive values, and (2) their relative contributions often show major seasonal fluctuations (Tenore 1988)

The few existing studies assessing temporal changes in the quality of POM are based on an empirical approach involving bioassays (Marsh et al. 1989, Cheng et al. 1993, Charles et al. 1995b). Due to (1) correlation effects and (2) the multiplicity of potential limiting factors it remains in fact very difficult to relate 
unambiguously observed changes in nutritive values with the availability of a single (class of) biochemical compound(s) (Grémare 1994). Another problem is the nature of the measured physiological variable. Both ingestion/absorption (Charles et al. 1995b) and growth (Marsh et al. 1989, Cheng et al. 1993) have already been used to infer temporal changes in the nutritive value of natural POM available for deposit-feeding invertebrates. As opposed to growth, ingestion and absorption can be directly incorporated into models of the functioning of benthic trophic networks (Pace et al. 1984, Chardy 1987. Chardy \& Dauvin 1992). On the other hand, the methodology involved in the measure of ingestion and absorption of benthic invertebrates fed on natural POM is still questionable, mostly due to potential problems in labeling procedures (Charles et al. 1995a).

During a previous study (Charles et al. 1995b), we reported on temporal changes in the nutritional values of sediment trap materials collected in the coastal zone of the western Mediterranean. This study was based on a 1 yr temporal series of field trap collection (periodicity: 1 wk), and on laboratory bioassays involving the quantification of ingestion and absorption rates of the deposit-feeding bivalve Abra ovata fed on sediment trap material collected at 8 different dates of the year. This work led us to conclude that the quality of sedimenting POM shows marked temporal fluctuations. However, there was no direct assessment of the response of the field benthic community during this particular study. The present work aims at completing

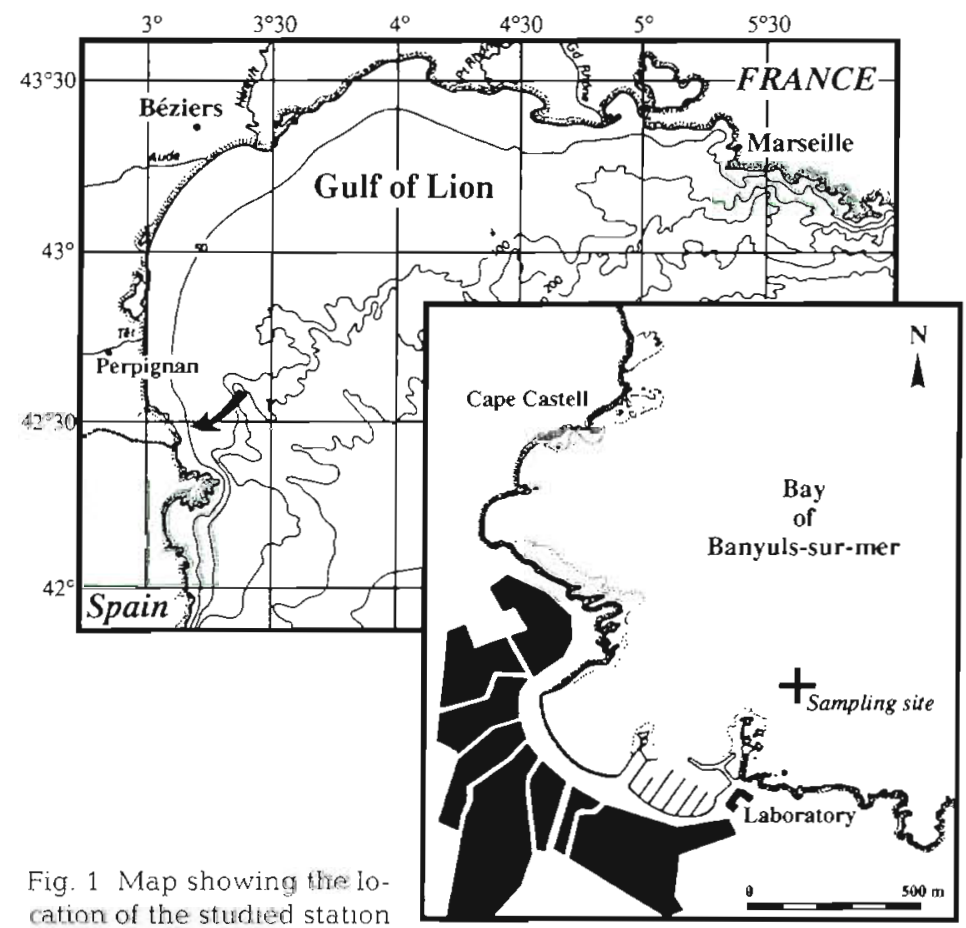

this preliminary approach by (1) considering a 2 yr period, (2) providing information on the availability of several compounds supposedly important for marine invertebrates (namely available proteins and essential amino acids), (3) assessing the response of 1 component of the benthic fauna (i.e. meiofauna) to gross sedimentation, and (4) carrying out bioassays based on growth measurements of $A$. ovata.

\section{MATERIALS AND METHODS}

Sediment traps. Two sediment traps were deployed between May 1992 and May 1994 at an $18 \mathrm{~m}$ deep station $\left(42^{\circ} 29.082^{\prime} \mathrm{N}, 03^{\circ} 08.421^{\prime} \mathrm{E}\right)$ in the bay of Banyuls-sur-Mer (northwestern Mediterranean) (cf. Fig. 1). These traps consisted of polyethylene pipes prolonged by a cone and a collector (Charles 1994). The inner diameter of the pipe was $40 \mathrm{~cm}$ with a total height of $190 \mathrm{~cm}$ giving an aspect ratio of 4.75 . The mouths of the traps were located $3 \mathrm{~m}$ above the sediment surface.

Biochemical assays. The contents of the traps were collected weekly by SCUBA diving They were taken to the laboratory where they were centrifuged (4000 rpm, $3000 \times g, 15 \mathrm{~min}$ ), frozen, briefly rinsed with distilled water and freeze-dried. This material was then sieved on a $200 \mu \mathrm{m}$ mesh and stored at $-20^{\circ} \mathrm{C}$. Organic contents were assessed by measuring the weight lost after combustion $\left(450^{\circ} \mathrm{C}\right.$ for $\left.5 \mathrm{~h}\right)$. Carbon and nitrogen contents were measured using a $\mathrm{CHN}$ Perkin Elmer 2400 analyzer Protein contents were measured on triplicates using the Lowry procedure (Lowry et al. 1951) as modified by Rice (1982) to account for the reactivity of phenolic compounds. Available protein contents were measured on triplicates using the procedure proposed by Mayer et al. (1986) Carbohydrate contents were measured on triplicates using the procedure of Dubois et al. (1956). Lipid contents were measured on triplicates using the procedure of Barnes \& Blackstock (1973). Combined amino acids were analyzed after acidification on triplicates with high performance liquid chromatography of precolumn derivatives after Lindroth \& Moper (1979).

Laboratory assays of nutritional values. Specimens of the deposit-feeding bivalve Abra ovata were collected in the Sigean lagoon (Western Mediterranean). They were then kept in the laboratory in tanks receiving running ambient seawater. Clams were progressively adapted to experimental conditions $\left(18^{\circ} \mathrm{C}, 38 \%\right)$. They were starved $24 \mathrm{~h}$ be- 
fore the experiment. At the beginning of the experiment, groups of 10 bivalves (average shell perimeter of $19.6 \mathrm{~mm}$ ) were randomly introduced in one of three $10 \mathrm{~cm}$ Pyrex bowl containing a fine layer of cleaned (rinsed in tap water for $24 \mathrm{~h}$ and then frozen) sediment ( $80 \%$ sand and $20 \%$ mud). The bowls were placed at random in 4 trays filled with standing (but aerated) filtered $(1.2 \mu \mathrm{m})$ seawater. There were 3 replicates per treatment. Each of the treatment ran for $28 \mathrm{~d}$ with sediment trap materials harvested at each of the following dates (September 29, 1992, October 13, 1992, November 1992, January 5, 1993, March 2, 1993, and May 1993) and with a daily ration of organic matter of $14 \mathrm{mg}$ bowl ${ }^{-1}$ based on preliminary trials showing that this ration results in maximal growth for clams fed with Tetramin (Baudart 1994).

These dates were selected to account for different meteorological situations. The materials collected on September 29, 1992, January 5, 1993, and March 2, 1993, are characterized by high gross sedimentation rates (GSR; strong winds) and low organic contents. The material collected in October 13, 1992, is characterized by a high GSR due to abundant precipitation with a high $\mathrm{C} / \mathrm{N}$ ratio. The material collected in November 1992 is characterized by a low GSR and a high organic content. This material is characteristic of the low energy events that may be occasionally observed during fall and winter The material collected in May 1993 is characterized by a low GSR and a high organic content. This material is characteristic of the regime which is observed during spring and summer.

Three replicated controls (no food addition) were carried out simultaneously with the other treatments. To prevent any effect due to food accumulation, we replaced the sediment in each bowl and the water in each tray every week. At the end of the experiment (28 d), clams were measured using an image analysis system composed of a stereo-microscope, a video-camera and a micro-computer equipped with the image analysis software Mocha (® Jandel Scientific). Shell perimeter was used as biometrical index (Baudart 1994).

Field measurement of pigment concentrations and meiofauna densities. Between March 30, 1993, and May 25, 1994, samples were taken monthly (manually sampled by SCUBA divers) to assess photosynthetic pigment concentrations and moisture in the upper $1 \mathrm{~cm}$ of the sediment and meiofauna densities. Each month, 4 cores $(5.4 \mathrm{~cm}$ in diameter) were sampled for pigment analysis. Immediately after sampling, cores were stored frozen at $-20^{\circ} \mathrm{C}$ before analysis. All subsequent manipulations were done at dim light and low temperature. During thawing, while the sediment was still partially frozen, the upper part of the cores was carefully sliced into 2 segments $(0-0.5$ and $0.5-1 \mathrm{~cm})$, collected in glass vials. Each layer was manually homogenized before subsampling. A subsample was used for moisture determination, another one for pigment analysis $(1 \pm 0.0001 \mathrm{~g}$ wet weight) Extraction in $90 \%$ acetone and further manipulations were conducted following Riaux-Gobin \& Klein (1993). Chlorophyll a (including isomers), $b$ and $c(c h l a, b$ and $c$ ) and the associated phaeopigments (phaeo $a, b$ and $c$ ) were measured using a spectrofluorometric technique (Neveux \& Lantoine 1993) slightly adapted to sediments. Results were expressed in $\mu \mathrm{g}$ pigment per gdry weight of sediment $\left(\mu \mathrm{g} \mathrm{g}^{-1} \mathrm{DW}\right.$ ). This method does not discriminate between chl $a_{1}$ chlorophyllide $a$, and iso- and allomers of chl $a$. Furthermore phaeo a includes phaeophytin $a$, phaeophorbide $a$, and other pigments of which phaeophorbide a-like pigments are often very important in recent sediments (Riaux-Gobin et al. 1987, Klein \& Riaux-Gobin 1991)

Each month, 4 cores ( $2 \mathrm{~cm}$ in diameter) were taken for meiofauna analysis. Thus, each sample referred to $3.14 \mathrm{~cm}^{2}$ of bottom surface and to the oxygenated upper layer of sediment (during the present study, the thickness of this layer ranged between 4 and $7 \mathrm{~cm}$ ). Extraction of the soft organisms was carried out by 7 repeated shakings in $5 \mathrm{l}$ of tap water and by sieving on a $40 \mu \mathrm{m}$ mesh. Metazaan meiofauna sensu Vitiello \& Dinet (1979) was then fixed in 10\% formalin and stained with Rose Bengal. Samples were counted under a dissecting microscope.

\section{RESULTS}

\section{Sediment traps}

Sediment traps were recovered 97 times during the study period. Gross sedimentation rates (GSR) were defined as the total amount of material sampled in a sediment trap with a known cross-sectional area over a known length of time. The temporal changes of GSR are presented in Fig. 2. GSR were between 0.6 and $317.8 \mathrm{~g} \mathrm{DW} \mathrm{m}^{-2} \mathrm{~d}^{-1}$ A harmonical analysis (periodogram not shown) showed the existence of an annual cycle (apparent period of the series: $51 \mathrm{wk}$ ). Within each of the 2 studied years, it was possible to distinguish 2 different periods by looking at GSR. The first one was characterized by relatively low and constant GSR and more or less corresponded to spring and summer The second one was characterized by relatively high and highly variable GSRs and mostly corresponded to fall and winter The relative durations of these 2 periods were different in 1992 and 1993 (28 and 18 wk respectively for the period characterized by high GSR). Average GSR recorded during fall and winter did not differ between 1992-1993 and 


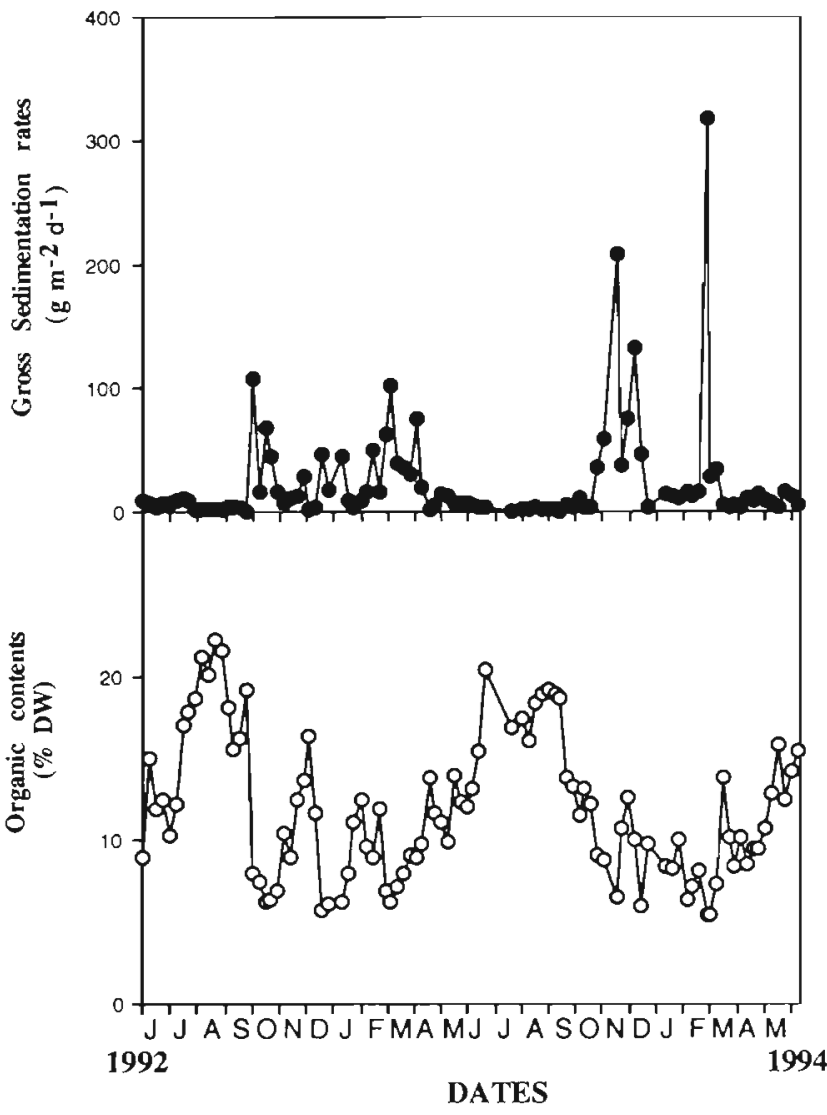

Fig. 2. Sediment traps. Temporal changes of gross sedimentation rates and organic contents

1993-1994 (Student $t$-test, $p=0.56$ ). Average GSR recorded during spring and summer were significantly higher in 1994 than in 1993 and 1992 (1-way ANOVA and associated a posteriori LSD tests, $\mathrm{p}=$ 0.03 ). We believe that this result was an artifact because: (1) our temporal series ended at the begin-

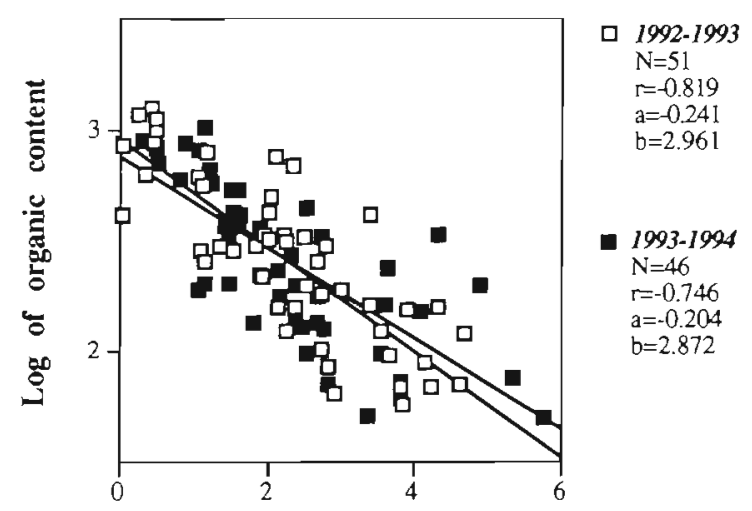

Log of gross sedimentation rate

Fig. 3. Sediment traps. Relatıonship between organıc content and gross sedimentation rate for the 2 studied years ning of June 1994, and (2) GSR were lower during summer than during spring Since then, the analysis of GSR at the same site is still going on. We were able to run the same statistical treatment with all the spring and summer GSR data corresponding to 1994. In this last case the ANOVA showed no significant differences in average spring and summer GSR among years $(\mathrm{p}=0.44)$.

The organic contents of sediment trap materials are presented in Fig. 2. Organic contents ranged from 5.5 (February 18, 1994) to $22.2 \%$ DW (August 18, 1992). This parameter followed an annual cycle (apparent

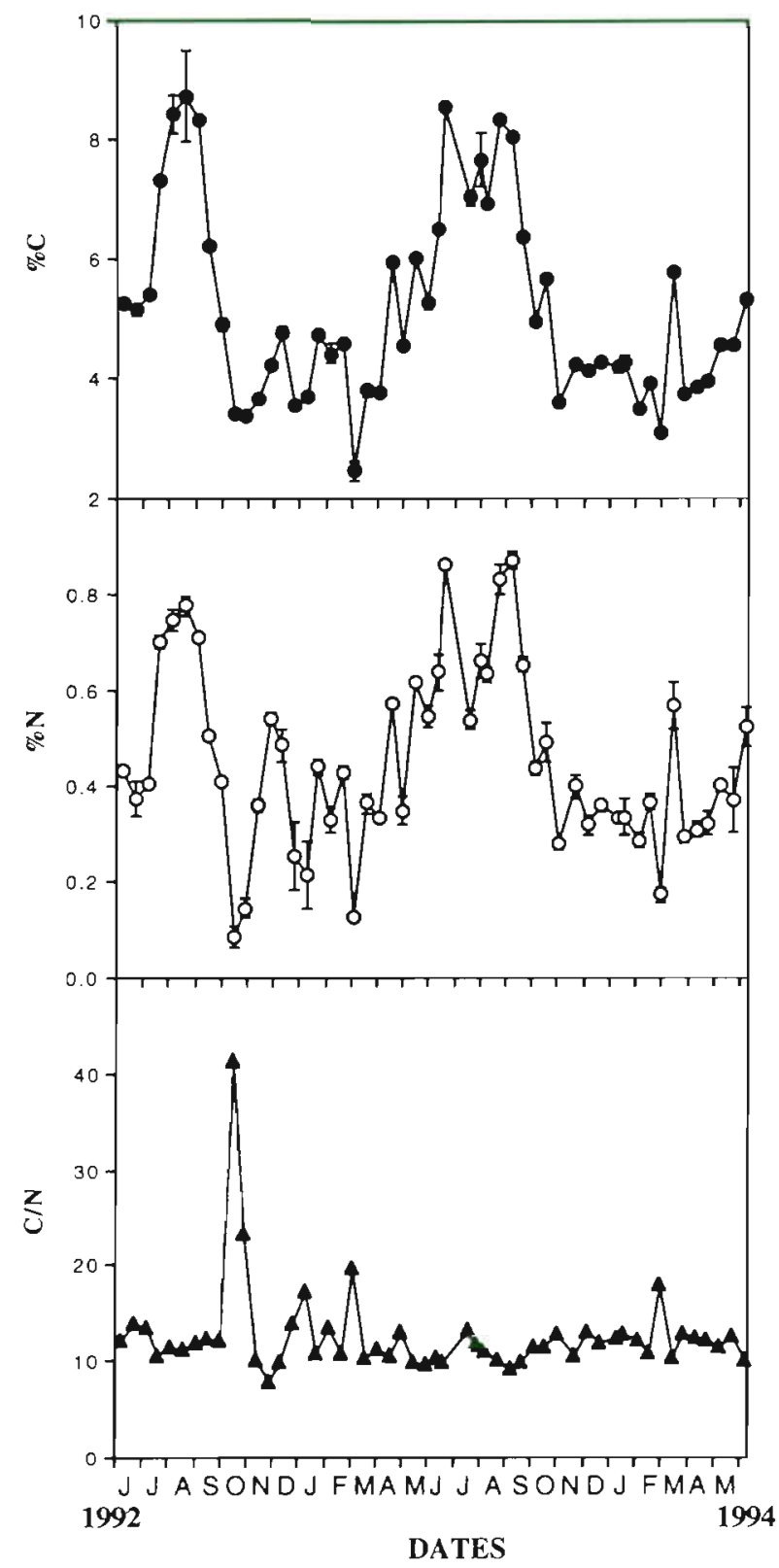

Fig. 4. Sediment traps. Temporal changes of carbon contents nitrogen contents, and corresponding $\mathrm{C} / \mathrm{N}$ ratios 
period of 51 wk). There was a negative correlation between GSR and organic contents (Fig. 3). This relationship was not significantly different for the 2 studied years (ANCOVA, $p=0.87$ ).

Carbon and nitrogen contents of the sediment trap materials are presented in Fig. 4 together with the corresponding $\mathrm{C} / \mathrm{N}$ ratios. Carbon contents ranged from 2.4 (March 2, 1993) to 8.4\% DW (August 4, 1992). Nitrogen contents ranged from 0.1 (February 18, 1994) to $0.9 \% \mathrm{DW}$ (September 1, 1993). Both of these parameters follow an annual cycle (apparent period of $50 \mathrm{wk}$, periodograms not shown). C/N ratios fluctuated. around a mean value of 11 with the occurrence of exceptionally high values during the second half of October 1992

Carbohydrate and lipid contents of the sediment trap materials are presented in Fig 5. Carbohydrate contents ranged from 16.0 (February 18, 1994) to $77.7 \mu \mathrm{g}$ $\mathrm{mg}^{-1}$ DW (August 24, 1993). Lipid concentrations ranged from 0.8 (January 5, 1993) to $35.4 \mu \mathrm{mg}^{-1} \mathrm{DW}$ (April 13, 1994). Both of these parameters followed an annual cycle (apparent period of $50 \mathrm{wk}$, periodograms not shown), although this pattern seemed less clear for lipids.

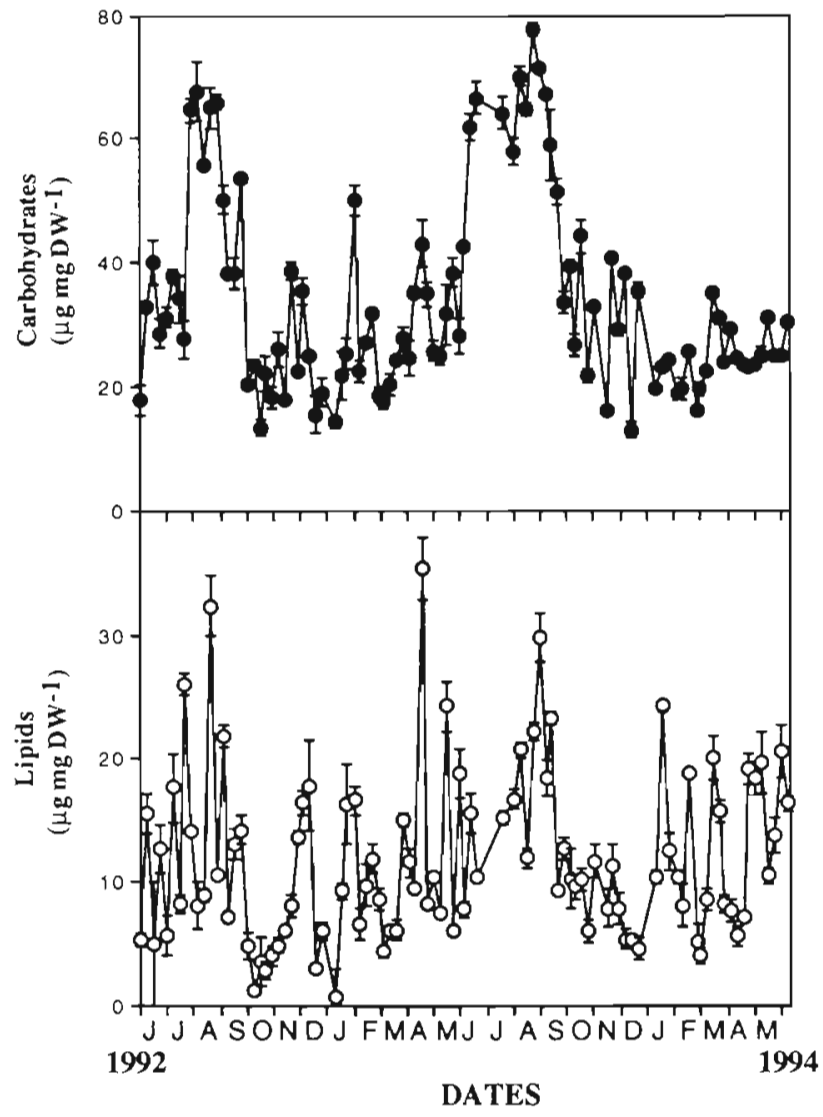

Fig. 5. Sediment traps. Temporal changes of the carbohydrate and lipid contents
Total and available protein contents of the sediment trap materials are presented in Fig. 6. Total protein concentrations ranged from 1.9 (March 2,1993 ) to $35.2 \mu \mathrm{g}$ $\mathrm{mg}^{-1}$ DW (March 8, 1994). Available protein contents ranged from 0.7 (February 18,1994 ) to $21.9 \mu \mathrm{g} \mathrm{mg} \mathrm{m}^{-1}$ DW (July 28, 1992). Both of these parameters followed an annual cycle (apparent period of $50 \mathrm{wk}$, periodograms not shown).

Total and essential amino acid contents of the sediment trap materials are presented in Fig. 7 Total amino acid concentrations ranged from 34.3 (March 2, 1993) to $273.8 \mu \mathrm{M} \mathrm{mg}^{-1} \mathrm{DW}$ (June 15, 1993). Available amino acid contents ranged from 14.2 (October 27, 1992) to $92.4 \mu \mathrm{M}$ $\mathrm{mg}^{-1}$ DW (September 1, 1993). Both of these parameters followed an annual cycle (apparent period of $52 \mathrm{wk}$, periodograms not shown) Interestingly, the relative contributions of each individual amino acid to the total pool were almost constant over time as reflected by the strong correlation between total and essential amino acid contents (Fig. 8; $p<0.0001$ ). A typical example of the contribution of each amino acid is given in Fig. 9 . Aspartic acid/asparagin, glutamic acid/glutamin, glycine and alanine were clearly dominant. Histidine, taurine and tyrosine were the least represented.

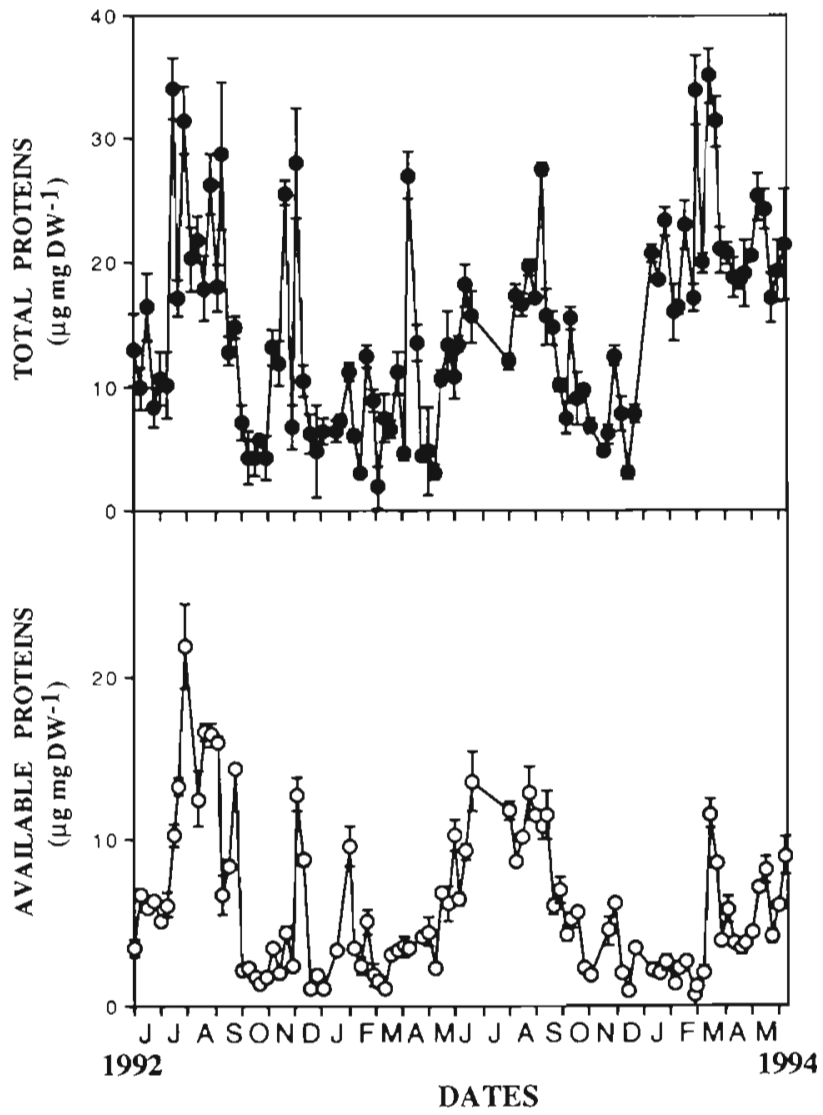

Fig. 6. Sediment traps. Temporal changes of the total and available protein contents 


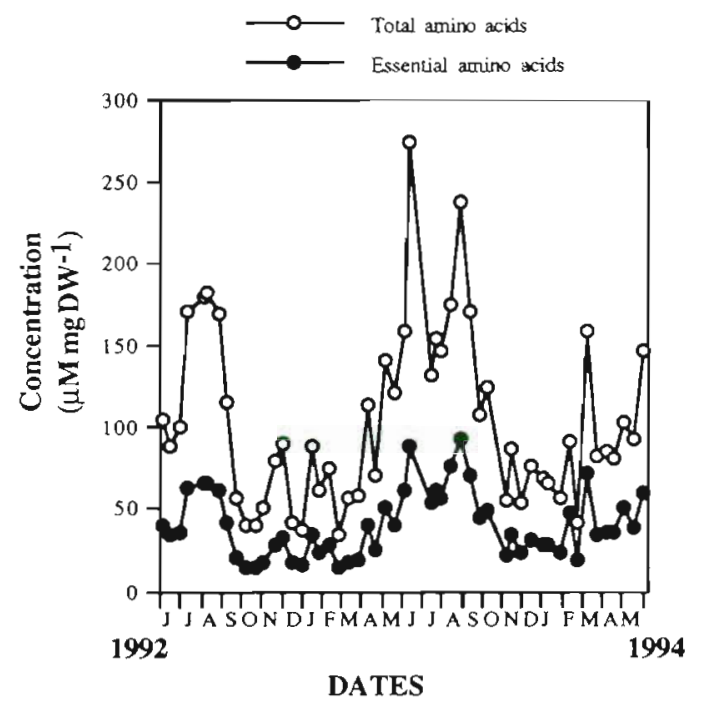

Fig. 7 Sediment traps. Temporal changes of the total and essential amino acid contents

\section{Laboratory assays}

The bivalve Abra ovata clearly presented different growth rates when fed on sediment trap materials collected at different dates (1-way ANOVA, $p<0.0001$ ) (cf. Fig. 10). Average increase in shell perimeter ranged from 0.0 (controls) to $1.1 \mathrm{~mm}$ (May 1993). A posteriori Fisher's LSD tests of mean comparisons (also shown in Fig 10) show that: (1) sediment trap material collected during May 1993 resulted in higher growth rates than all the other tested foods, (2) material collected on March 2, 1993, induced higher increase in shell perimeter than all the other tested foods except the material collected in May 1993, and (3) there was

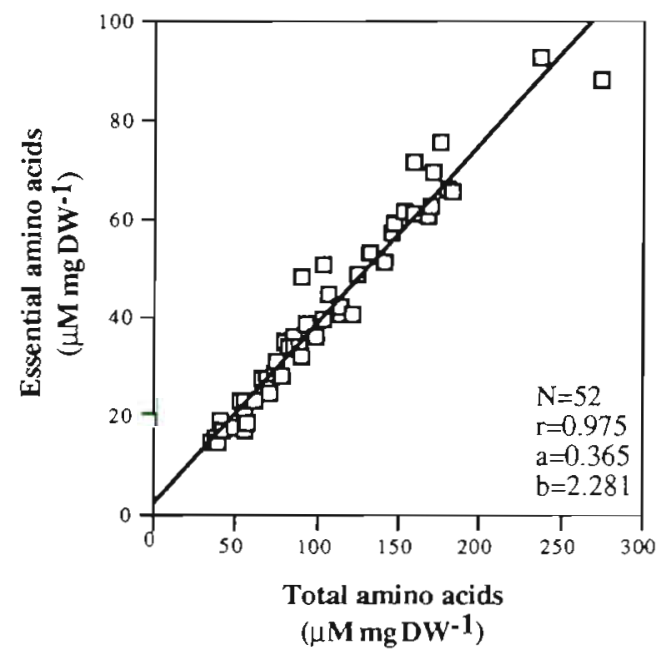

Fig. 8. Sediment traps. Relationship between total and essential amino acid contents no significant difference between increases in shell diameter observed for controls and clams fed on material collected on September 29, 1992. Determination coefficients corresponding to linear regression models linking daily rations in various biochemical compounds (independent variables) and average increase in shell perimeter (dependent variables) are presented in Table 1 There was no significant correlation for $\mathrm{C}$, $N$, proteins, carbohydrates and essential amino acids. Both available proteins (cf. Fig. 11) and lipids provided a reasonably good description of growth i.e. description of 69.2 and $68.0 \%$ of the total variance, respectively).

\section{Field measurements}

During the period under study, the pigment composition of the sediment was clearly dominated by chl a and its derivatives (phaeo a) (cf. Fig. 12). Concentrations of chl a were significantly affected both by the date of harvest and by depth (2-way ANOVA, p < 0.0001 in both cases with a significant interaction). Concentrations of chl a within the first $0.5 \mathrm{~cm}$ were between 0.7 (November 1993) and $3.5 \mu g g^{-1} \mathrm{DW}$ (May 1993), thus showing a marked peak during late spring 1993. Concentrations of chl a between 0.5 and $1 \mathrm{~cm}$ were generally lower and their temporal changes appeared less marked. Phaeo a concentrations were significantly affected both by the date of harvest and by depth (2-way ANOVA, p $<0.0001$ and $p<0.0002$, respectively, with no significant interaction). Concentrations in phaeo a within the first $0.5 \mathrm{~cm}$ of sediment appeared closely related to chl a $(\mathrm{r}=$ $0.634, \mathrm{n}=14, \mathrm{p}<0.02$ ). Besides the spring peak, con-

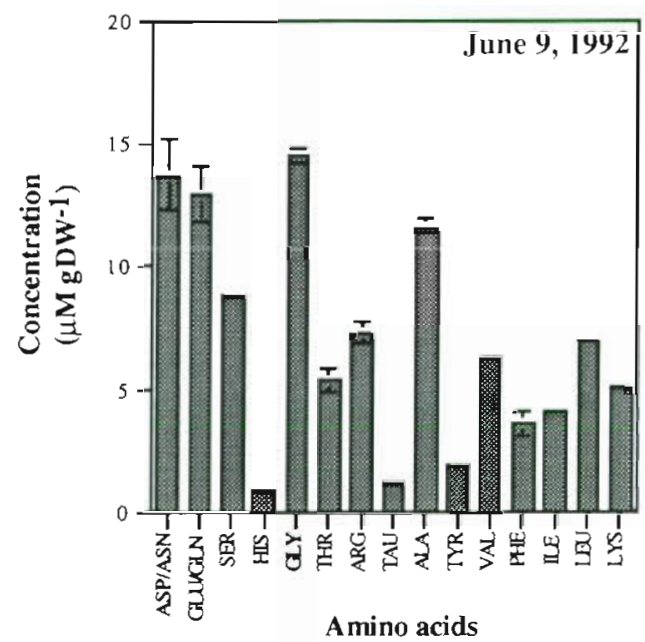

Fig. 9. Sediment traps. Example of the relative contribution of each amino acid 


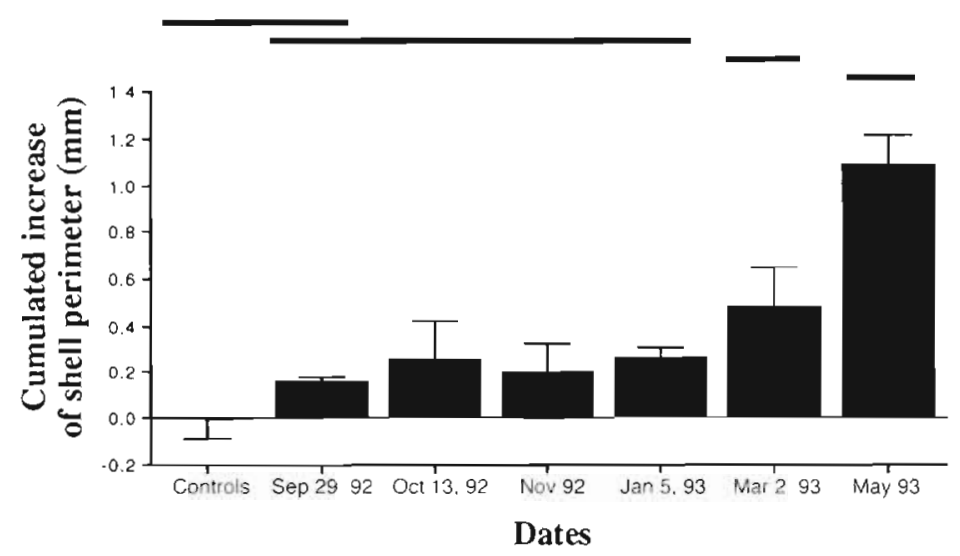

Fig. 10. Laboratory assays. Average increases in shell perimeter recorded for clams fed on the 6 tested foods. Horizontal lines show the results of a posteriori LSD mean comparison tests

centrations in phaeo a also seemed to increase during February and April 1994, however it should be stressed that the corresponding measures were characterized by a very high variability. Concentrations in chl $b$ and phaeo $b$ always remained very low, close to the lower limits of detection (i.e. less than $0.17 \mu \mathrm{g} \mathrm{g}^{-1}$ DW, phaeo b, May 1993) (cf. Fig. 12). This may suggest that Euglenophyceae, Prasinophyceae and Chlorophyceae were absent from the site. Concentrations of chl $c$ were significantly affected both by the date of harvest and by depth (2-way ANOVA, p < 0.0001 in both cases with a significant interaction) (cf Fig. 12). Concentrations of $\mathrm{chl} c$ within the first $0.5 \mathrm{~cm}$ were between 0.1 (November 1993) and $0.6 \mu \mathrm{g} \mathrm{g}^{-1}$ DW (May 1993). They followed the same pattern as chl $a(r=0.957, n=14, p<0.0001)$, thereby suggesting that Chromophytes (and probably Bacillariophyceae) were dominant within the studied site. Temporal changes of phaeo $c$ concentrations within the first $0.5 \mathrm{~cm}$ of the sediment appeared closely related to $\mathrm{chl} c$. Temporal changes of both $\mathrm{chl} C$ and phaeo $C$ concentrations between 0.5 and $1 \mathrm{~cm}$ were difficult to

Table 1 Laboratory assays. Determinung coefficients $\left(\mathrm{r}^{2}\right)$ and associated probabilities $(p)$ corresponding to linear regression models linking daily ratıons in various brochemucal compounds (descriptors) and cumulated increases in Abra ovata shell perimeters

\begin{tabular}{|lcc|}
\hline Descriptor & $\mathrm{r}^{2}$ & $\mathrm{p}$ \\
\hline $\mathrm{C}$ & 0.050 & 0.62 \\
$\mathrm{~N}$ & 0.244 & 0.26 \\
Total proteins & 0.025 & 0.73 \\
Carbohydrates & 0.227 & 0.28 \\
Lipids & $\mathbf{0 . 6 8 0}$ & $\mathbf{0 . 0 2}$ \\
Available proteins & $\mathbf{0 . 6 9 2}$ & $\mathbf{0 . 0 2}$ \\
Essential amino acids & 0.520 & 0.07 \\
\hline
\end{tabular}

interpret in terms of seasonality. The chl al phaeo a ratio was maximum (i.e. $>1.1$ ) between May and August 1993, and minimum (0.5 to 0.8 ) during winter The chl a/chl $c$ ratio was not constant 6 to 7 from May to June 1993, around 12 thereafter and up to 14 in December 1993 and February 1994).

Temporal changes in the density of tota] meiofauna are presented in Fig. 13. Total densities were significantly affected by the sampling date (1-way ANOVA, $p<0.0001)$. They ranged from 346 (November 1993) to 1207 ind. sample-1 (April and May 1993). They were significantly correlated with concentrations of chl a within the first $0.5 \mathrm{~cm}$ of sediment $(r=0.684, n=13, p<0.01)$. Meiofauna was clearly dominated by nematodes, which always accounted for more than $90 \%$ of the total. Densities of nematodes were maximal during April and May 1993, whereas densities of copepods were maximal during July and August 1994. Densities of polychaetes showed no marked peak.

\section{DISCUSSION}

\section{Field measurements: sediment traps}

GSR recorded during the present study ranged between 0.6 and $317.8 \mathrm{~g} \mathrm{~m}^{-2} \mathrm{~d}^{-1}$ (vs 0.6 and $107.8 \mathrm{~g}$ $\mathrm{m}^{-2} \mathrm{~d}^{-1}$ for the $1 \mathrm{yr}$ study already carried out by Charles et al. 1995b) for the same site. These values are of the same order of magnitude as similar data

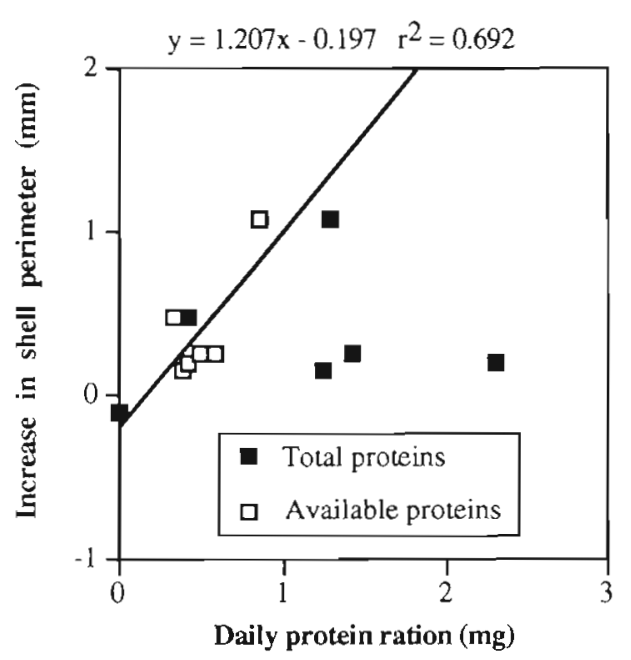

Fig. 11 Laboratory assays. Relationships between total and available protein daily rations and average increases in shell perimeter 


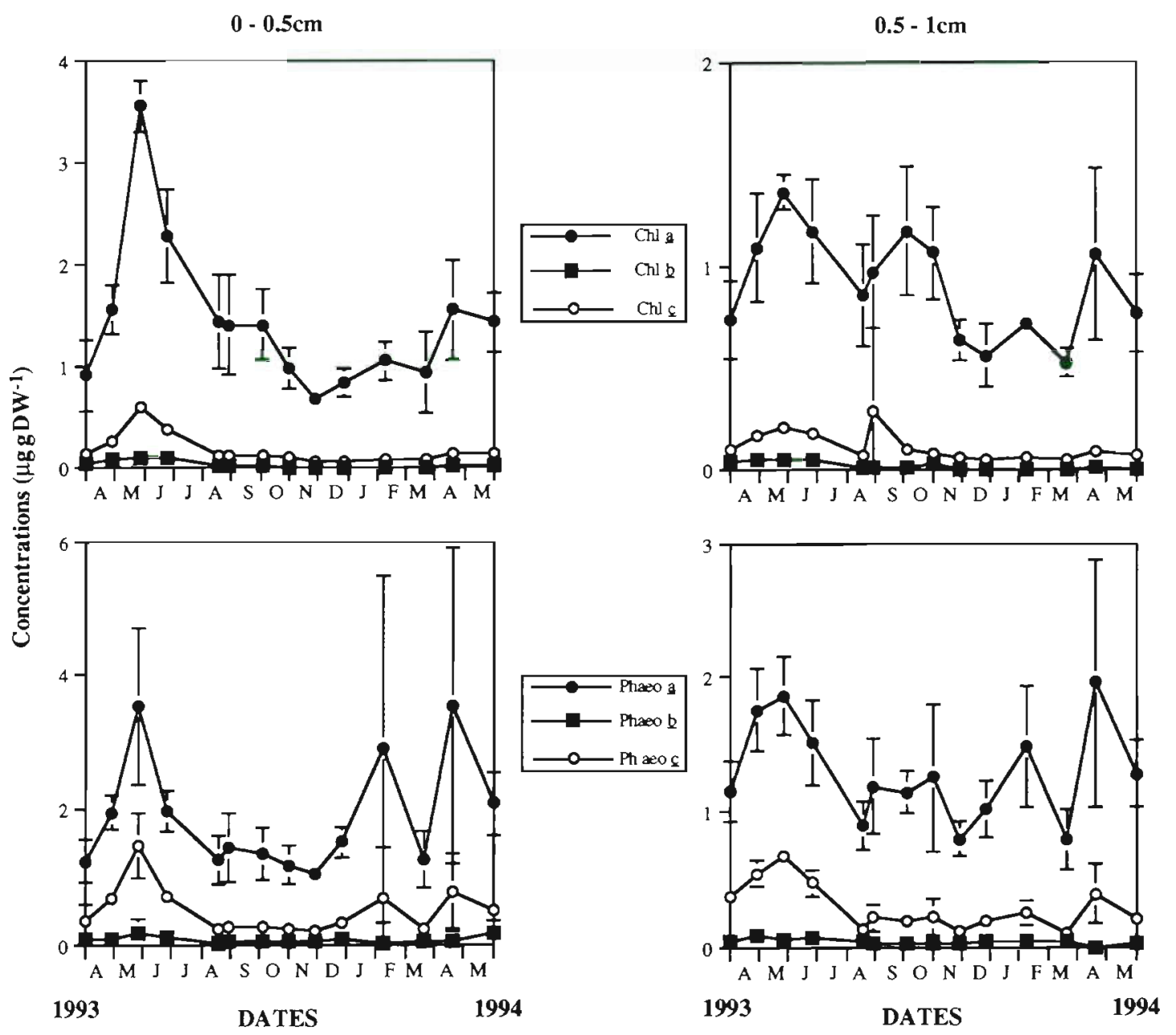

Fig. 12. Field measurements. Temporal changes of chlorophylls and phaeophytins $a, b$ and $c$ within the first $1 \mathrm{~cm}$ of sediment

from a $30 \mathrm{~m}$ deep station located at Saint-Cyprien, France (GSR ranging from 4.5 to $319.0 \mathrm{~g} \mathrm{~m}^{-2} \mathrm{~d}^{-1}$ ) (Buscail 1991). Thus differences in maximal GSR values between Buscail (1991) and Charles et al. (1995b), which were previously attributed to the location of the openings of the traps (Charles et al. $1995 b)$, indeed probably mainly result from interannual variability. As shown by Charles et al. (1995b) GSR vary strongly with a seasonal component showing high sedimentation rates during fall and winter, and low sedimentation rates during spring and summer. Data from the present study allow us to subdivide further the spring and summer period into 2 subperiods, because GSR recorded during spring are usually slightly higher than those recorded during summer The negative relationship between the organic content (and the main biochemical characteristics) of the sediment trap materials and GSR is identical to the one reported by Charles et al. (1995b). This result supports the role of sediment resuspen- sion in controlling GSR fluctuations at the studied site (Charles et al. 1995b).

To our knowledge, this is the first report of available protein contents in sediment trap materials. The concentrations measured during the present study range between 0.7 and $21.9 \mu \mathrm{g} \mathrm{mg}^{-1} \mathrm{DW}$. The maximal value is thus much higher than literature data regarding superficial sediment $\left(2.2 \mu \mathrm{g} \mathrm{mg}^{-1} \mathrm{DW}\right.$ according to Mayer et al. 1986, $2.7 \mu \mathrm{g} \mathrm{mg}^{-1} \mathrm{DW}$ according to Mayer \& Rice 1992 , and $0.9 \mu \mathrm{g} \mathrm{mg}^{-1}$ DW according to Carey \& Mayer 1990). The same is true for the ratio of available protein nitrogen to total nitrogen (between 4.1 and $55.7 \%$ assuming a conversion factor of 0.16 between available protein and available protein nitrogen; Mayer et al. 1986). This probably reflects the higher quality of material originating from the water column. This interpretation is further supported by the negative relationship linking GSR and the ratio of available protein nitrogen to total nitrogen $(r=-0.650, n=48, p<$ 0.01 , data not shown). 


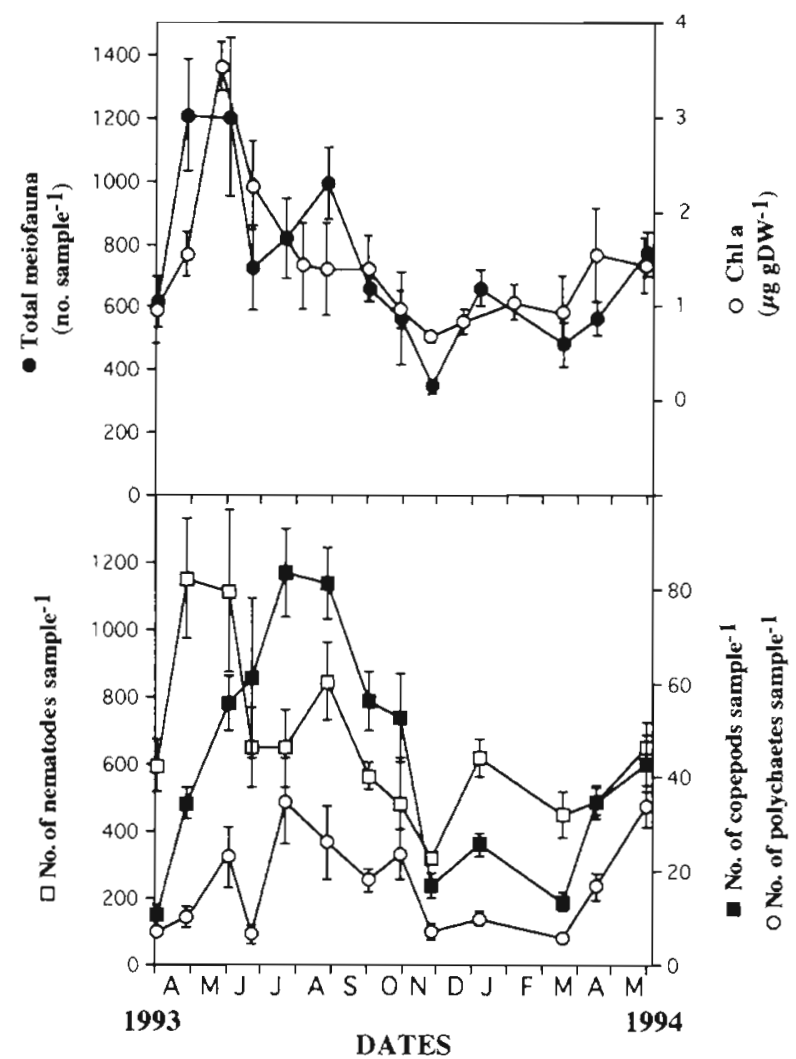

Fig. 13. Field measurements. Temporal changes of the densities within the major components of meiofauna. Temporal changes of chlorophyll a within the first $0.5 \mathrm{~cm}$ have been included in the upper part of the figure to show the good correlation between total meiofauna and pigment concentration

\section{Field measurements: pigment concentrations} and meiofauna

The pigment concentrations recorded during the present study can be compared with similar data from a series of 5 sites (ranging from 5 to $35 \mathrm{~m}$ depth) in Banyuls Bay that were sampled every other month between March 1990 and March 1993 (C. Riaux-Gobin et al. unpubl.). These data also show a clear seasonal pattern, at least for the deeper sediments, with chl a concentrations up to $3 \mathrm{\mu g} \mathrm{g}^{-1}$ DW during summer months. In a general way, the present data concerning chl a are thus closer to those obtained at the sandy sites, whereas the chl a/phaeo a ratios are closer to those obtained at muddy deeper sediments. The chl al phaeo a ratio is maximal (i.e. $>1.1$ ) between May and August 1993, and minimal (i.e. between 0.5 and 0.8) during winter This may reflect the presence of an autochthonous microphytobenthic assemblage during the summer months, followed by a period of degraded pigment accumulation developed by: (1) intense grazing by meio- or macrofauna, (2) natural decay of the microphytic assemblage under unfavorable conditions (low temperature and light), and (3) sedimentation of local degraded phytoplankton. The variation of the chl a/chl cratio is also quite different from those previously obtained, which rarely reached 9 for all sediment types. In the literature this ratio is around 9 for Bacillariophyceae and usually higher in Phaeophyceae (Rowan 1989). The high values during winter may thus be linked to resuspension events or to allochthonous particle drift (for example associated with river discharges).

Meiofauna densities recorded during the present study follow a clear seasonal pattern characterized by a single maximum of abundance during April and May. The occurrence of a single peak of abundance is in good agreement with existing data regarding other sublittoral meiofaunal Mediterranean communities (Dinet 1972, Nodot 1978), although more complicated patterns have been reported (see Soyer 1985 for review), especially for very shallow habitats in the immediate proximity of dense macroalgal populations (Bodiou et al. 1990). During the present study, the peak of meiofauna abundance was due to nematodes, which accounted for about $90 \%$ of total meiofauna. The density of harpacticoid copepods was maximal during July and August, which corresponds to one of the peaks reported by Bodiou et al. (1990). These authors used a principal component analysis to assess the relationship between copepod densities and concentrations of organic carbon and nitrogen within the sediment. They concluded that populations were mainly controlled by meteorological events during winter and spring, and rather food limited during summer and fall. In spite of evident limitations (see Montagna et al. 1983), regression models can also be used to assess the relationship between food availability and meiofauna density (Montagna et al. 1983). During the present study, this approach showed an excellent relationship when using sediment chl a concentration as an independent variable. The relationship linking meiofauna and primary producers including benthic diatoms has already been underlined by many authors (Montagna et al. 1983, Romeyn \& Bouwman 1983). Montagna et al. (1983) reported a significant correlation between the concentration of benthic diatoms and the densities of several species of harpacticoid copepods. These authors, however, concluded that diatoms were probably not the sole limiting factor of the populations due to the absence of correlation during secondary peaks of copepods density. Along the same lines, Rudnick et al. (1985) suggested that in Narragansett Bay, USA, increasing temperature during spring may interact with the sedimentation of phytoplanktonic detritus during winter to control the burst of meiofaunal populations during late spring. It is thus interesting to notice that, in the 
present study, there was a tight correlation between chl a concentration and meiofauna density throughout the sampling period. This observed relation may suggest that at the studied depth (i.e. $18 \mathrm{~m}$ ): (1) the development of meiofaunal populations is not temperature limited during winter, and (2) the direct impact of hydrodynamism on meiofaunal populations is rather low. The time lag between maximal densities of nematodes and copepods could be related to the use of slightly different food sources as indicated by the sharp (i.e. from 6 to 12 ) increase in the $\mathrm{chl}$ a/chl $c$ ratio between June and July. In this sense it would be interesting to assess more fully the potential of macroalgal detritus as food sources for harpacticoid copepods as suggested by Bodiou et al. (1990)

\section{Laboratory assays: identification of a biochemical descriptor of food quality}

Nitrogen is commonly thought to be the limiting factor of the detritus food chain (Tenore 1988, Carey \& Mayer 1990). However, Tenore (1981, 1983) pointed out the interactive effect of available energy content as also influencing detritivore growth. It is also recognized that a large proportion of sediment nitrogen is bound into refractory materials and thus cannot be readily absorbed by primary consumers (Rice 1982, Mayer et al. 1986). This is why considerable efforts have been made to develop analytical protocols designed to quantify that particular proportion of the total nitrogen pool which is actually available to animals (Mayer et al. 1986, 1995). Such procedures are focused either on hydrolyzable polypeptides (Mayer et al. 1.986) or on bioavailable amino acids (Mayer et al. 1995). They involve enzymatic hydrolysis aiming at mimicking digestion

However, as stated by Mayer et al. (1995), 'a perfectly accurate in vitro method of nutrient assay is impossible'. During the present study, we have tried to associate bioassays (i.e. growth experiments) and biochemical assays. The idea was to compare the ability of biochemical parameters to describe the variance of. observed growth rates. Our data show that available proteins and lipids are the 2 best descriptors. This result thus supports the 'biomimetic' approach developed by Mayer et al. $(1986,1995)$ for the quantification of bioavailable nitrogenous compounds. In the future, it will be very interesting to compare the ability of available proteins and bioavailable amino acids to describe growth rates of benthic primary consumers. The good description provided by the daily ration in total lipids is in good agreement with the results obtained by Marsh et al. (1989) for juveniles of the deposit-feeding polychaete Capitella capitata type I reared on 6 diets. It probably reflects specific requirements for fatty acids (Phillips 1984). The poor description obtained when using essential amino acids as independent variable is probably due to (1) the constancy of their relative contribution and (2) the mode of hydrolysis which is used $(6 \mathrm{~N} \mathrm{HCl})$.

\section{Laboratory assays: consequences for the modeling of coastal benthic trophic networks}

The models of continental shelf food webs recently developed by Pace et al. (1984) and then Chardy (1987) and Chardy \& Dauvin (1992) are based on global descriptors of organic matter (e.g. carbon or energy). They suppose that the absorption efficiency of a given compartment is constant for all the consumed preys. Moreover, in these models, growth results from an energetic balance since it is obtained by difference between ingestion/absorption and metabolic losses.

\section{Existence of temporal fluctuations in food quality}

Our results clearly show the existence of a significant effect of sampling date on growth rate in the deposit-feeding bivalve Abra ovata. They support the existence of temporal changes in the quality of sedimenting material as already shown for the same field site by other bioassays based on ingestion and absorption rates (Charles 1994, Charles et al. 1995b). Our data are also in good agreement with the seasonal pattern reported by Cheng et al. (1993). Thus it now seems confirmed that the quality of POM available to coastal benthic deposit-feeders shows important seasonal fluctuations. This should now be included in models of benthic trophic networks. This can be done either by using an empirical approach based on the results of bioassays carried out on the studied site (as suggested by Charles et al. 1995b) or by determining a control function linking food quality and some of the biochemical characteristics of the available POM. This last approach is of course preferable, it is also much more difficult because it raises several problems associated with the nature of the bioassays and even to the conception of existing models of benthic trophic networks

\section{Nature of the bioassays}

As stated in the 'Introduction', 2 types of bioassays have been used to assess the quality of detritivores' food resources. The first one is based on ingestion and 
absorption (Frantzis \& Grémare 1993, Charles et al. 1995b), and the second one on gonadic or somatic production (i.e. growth) (Cammen 1980, Tenore 1983, Grémare et al. 1988, Marsh et al. 1989, Cheng et al. 1993, Frantzis \& Grémare 1993, Grémare 1994). Bioassays involving ingestion and absorption measurements are advantageous because they provide parameters that can be readily incorporated into existing models of benthic trophic networks. On the other hand such tests do not reflect the whole process of nutrition (the assimilation step being ignored). This point is of special importance when trying to relate differences in food quality with biochemical descriptors (Grémare et al. 1988, Marsh et al. 1989, Grémare 1994). The search for these descriptors is usually carried out by using regression models linking biochemical contents of the tested food sources and corresponding values of a physiological variable (Grémare et al. 1988, Marsh et al. 1989, Grémare 1994). The theoretical framework of this approach is the limiting theory, which states that the best description of the variance of a physiological variable is obtained when using its limiting factor as the independent variable of a regression model. There are of course several problems associated with the use of this approach for identifying biochemical descriptors of food quality, one of them being the possible existence of several limiting factors (see Grémare 1994 for review). It is nevertheless important to remember that potential limiting factors have always been identified based on specific nutritional requirements. For example, Phillips (1984) began his paper on the role of different substrates as potential suppliers of specific essential nutrients by stating 'all animals must obtain (in addition to sources of energy and proteins) certain specific essential nutrients in order to survive grow and reproduce. The purpose of this paper is to raise the question of how marine detritus-feeders are likely to obtain these specific, essential nutrients in their natural diets' It seems thus clear that bioassays aiming at identifying biochemical descriptors of food quality should not be based on ingestion and absorption. This assertion is further illustrated by the difficulty in finding any quantitative relationship between substrate characteristics and absorption efficiencies in the deposit-feeding bivalve Abra ovata (Charles et al. 1995b), and by the good correlation linking the rations of available proteins and the cumulative growth rates of the same bivalve (present study) At present, we are thus facing a contradiction: we should on the one hand carry out bioassays based on ingestion and absorption in order to provide data for trophic network models, yet on the other hand carry out bioassays based on growth for determining control functions describing changes in food quality.

\section{Consequences for current models of benthic trophic networks}

The existence of this paradox is further supported by the impossibility of describing major events of the benthos dynamics such as the seasonal decline of populations of opportunistic deposit-feeders by using energetic balance based on macronutrients (Marsh \& Tenore 1990). We believe that these discrepancies are due to some of the weaknesses of the existing models of coastal benthic trophic networks. These weaknesses concern primarily deposit-feeders because unlike selective herbivores and carnivores these organisms exploit foods that are typically heterogeneous in biochemical composition (Phillips 1984). Deposit-feeders exploit those foods at different rates depending on their nature and origin (Lopez \& Levinton 1987). Living microbes are for example much more readily absorbed than detritus, and detritus derived from phanerogams is much more refractory than that derived from seaweeds (Findlay \& Tenore 1982). It is thus clear that absorption efficiencies should also be a function of the consumed food. Moreover, because of the existence of potential limitations due to the impossibility of meeting specific nutritional requirements, growth should not simply be obtained by the difference between the quantities of absorbed, excreted and respired carbon (or energy). It would probably be better to incorporate a control function linking the amount of absorbed matter and growth. The results of the present study suggest that this function could be based on available proteins.

Acknowledgements. This work was partly funded through the Programme National d'Océanographie Côtière.

\section{LITERATURE CITED}

Barnes H. Blackstock J (1973) Estumation of lipids in marine animals and tissues: detailed investigation of the sulphosphovanillin method for 'total' lıpıds. J Exp Mar Biol Ecol 12:103-118

Baudart J (1994) Etude expérimentale des fluctuations qualitatives du matériel particulaire sédimentant en zone littorale. DEA, Unıversité Paris 6, p 1-34

Bodiou JY, Delille D. Tito de Morais L (1990) Influence of organic matter and clmatic factors on the harpacticoid copepod (Crustacea) population from the well sorted fine sands of Banyuls Bay. Helgolander Meeresunters 44: $265-274$

Buscail R (1991) Le cycle du carbone sur une marge continentale: aspects blogéochimiques du transfert de la matière organıque à l'ınterface eau-sédıment. Thèse Doctorat d'Etat, Unuersité de Perpignan

Cammen LM (1980) The significance of microbial carbon in the nutrition of the deposit-feeding polychete Nereis succinea. Mar Biol 61:9-20

Carey DA, Mayer LM (1990) Nutrient uptake by a depositfeeding enteropneust: nitrogenous sources. Mar Ecol Prog Ser 63:79-84 
Chardy P (1987) Modele de simulation du système benthique des sédiments grossiers du golfe normand-breton (Manche). Oceanol Acta 10:421-434

Chardy P, Dauvin JC (1992) Carbon flows in a subtidal fine sand community from the western English Channel: a simulation analysis. Mar Ecol Prog Ser 81:147-161

Charles F (1994) Etude expérimentale du niveau d'utilisation de matériel détritique d'origines différentes par le bivalve dépositivore Abra ovata. Thèse de Doctorat, Universite Paris 6, p 1-291

Charles F, Grémare A, Amouroux JM (1995a) On the utilization of ${ }^{14} \mathrm{C}$ formaldehyde to infer ingestion rates and absorption efficiencies of benthic deposit-feeders. Mar Ecol Prog Ser 127:121-139

Charles F, Grémare A, Amouroux JM, Baudart J (1995b) A bioassay approach to temporal variation in the nutritional value of sediment trap material. J Exp Mar Biol Ecol 19:65-81

Cheng IJ, Levinton JS, McCartney M, Martinez D, Weissburg MJ (1993) A bioassay approach to seasonal variation in the nutritional value of sediment. Mar Ecol. Prog Ser 94:275-285

Dinet A (1972) Etude écologique des vanations quantitatives annuelles d'un peuplement de copépodes harpacticoides psammiques. Téthys 4:95-112

Dubois M, Gilles KA, Hamilton JK, Rebers PA, Smith. F (1956) Colorimetric method for determination of sugars and related substances. Anal Chem 28:350-356

Findlay SEG, Tenore KR (1982) vitrogen source for a detritivore: detritus substrate versus associated microbes. Science 218:371-373

Frantzis A, Grémare A (1993) Ingestion, absorption, and growth rates of Paracentrotus Jividus (Echinodermata: Echinoidea) fed different macrophytes. Mar Ecol Prog Ser 95:169-183

Gremare A (1994) What describes fecundity of Capitella sp. I better: macro- or mıcronutrient availability? Mar Biol 119: $367-374$

Grémare A, Marsh AG, Tenore KR (1988) Short-term reproductive responses of Capitella capitata type I (Annelida: polychaeta) fed on different diets. J Exp Mar Biol Ecol 123: $147-162$

Klein B, Riaux-Gobin C (1991) Algal pigment diversity of sediments from Kerguelen (Sub-Antarctic Islands) reflecting local dommance of green algae, cuglenoids and diatoms. Polar Biol 11:439-448

Lindroth P, Moper K (1979) High performance liquid chromatographic determination of subpicomole amino acids by precolumn derivatization with o-phtaldialdehyde. Anal Chem 51:1667-1674

Lopez GR, Levinton JS (1987) Ecology of deposit-feeding animals in marne sediments. Q Rev Bıol 62:235-259

Lowry OH, Rosebrough NJ, Farr AL, Randall RJ (1951) Protein measurement with the Folin phenol reagent $J$ Biol Chem 193:265-275

Marsh AG, Grémare A. Tenore KR (1989) Effect of food type and ration on growth of juvenile Capitella sp. I (Annelida Polychaeta): macro- and micronutrients. Mar Bıol 102: $519-527$

Marsh AG, Tenore KR (1990) The role of nutrition in regulating the population dynamics of opportunistic surface deposit-feeders in a mesohaline community. Limnol Oceanogr 35:710-724

This article was presented by K. R. Tenore (Senior Editorial Advisor), Solomons, Maryland, USA
Mayer LM, Rice DL (1992) Early diagenesis of protein: a seasonal study. Limnol Oceanogr 37:280-295

Mayer LM, Schick LL, Sawyer T, Plante CJ, Jumars PA, Self RL (1995) Bioavailable amino acids in sediments: a biomimetic, kinetic-based approach. Limnol Oceanogr 40: $511-520$

Mayer LM, Schick LL, Setchell FW (1986) Measurement of protein in nearshore marıne sediments. Mar Ecol Prog Ser 30:159-165

Montagna PA, Coull BC, Herring TL, Dudley BW (1983) The relationship between abundances of meiofauna and theis suspected microbial food (diatoms and bacteria). Estuar Coast Shelf Sci 17:381-394

Neveux J, Lantoine F (1993) Spectrofluorometric assay of chlorophylls and phaeopigments using the least square approximation technique. Deep Sea Res 40:1747-1765

Nodot C (1978) Cycles biologiques de quelques espèces de copépodes harpacticoides psammiques. Téthys 8. $241-248$

Pace : IL Glasser JE, Pomeroy LR (1984) Simulation analysis of continental shelf food webs. Mar Brol 82:47-63

Phillips NW (1984) Roles of different microbes and substrates as potential suppliers of specific essential nutrients to marine detritivores. Bull Mar Sci 12:33-47

Rlaux-Gobin C, Klein B (1993) Microphytobenthic blomass measurement using HPLC and conventional pigments analysis. In: Kemp P, Sherr B, Sherr E, Cole J (eds) Current methods in aquatic microbial ecology. Lewis Publishers, Boca Raton, p 369-376

Riaux-Gobin C, Llewellyn CA, Klein B (1987) Microphytobenthos from two subtidal sediments from North Brittany. II: Variations of pigment composition and concentrations determined by HPLC and conventional techniques. Mar Ecol Prog Ser 40:275-283

Rice DL (1982) The detritus nitrogen problem: new observations and perspectives from organic geochemistry. Mar Ecol Prog Ser 9:153-162

Romeyn K, Bouwman LA (1983) Food selection and consumption by estuarine nematodes. Hydrobiol Bull 17:103-109

Rowan KS (1989) Photosynthetic pigments of algae. Cambridge University Press, Cambridge

Rudnick DT, Elmgren R, Frithsen JB (1985) Meiofaunal prominence and benthic seasonality in a coastal marine ecosystem. Oecologia 67:157-168

Sorer J (1983) Aediterranean sea meiobenthos. In: Kiortsis $V$ (ed) Mediterranean marine ecosystems. Plenum Publishing Corporation, New York, p 85-108

Tenore KR (1981) Organic nitrogen and caloric content of detritus. I. Utilization by the deposit-feeding polychaete Capitella capitata. Estuar Coast Shelf Sci 12:39-47

Tenore KR (1983) What controls the avarlability to animals of detritus derived from vascular plants: organic nitrogen enrichment or caloric availability? Mar Ecol Prog Ser 10: $307-309$

Tenore KR (1988) Nitrogen in benthic food chains. In: Blackburn. $T H$, Sorensen $J$ (eds) Nitrogen cycling in coastal environment. Scope, John Wiley \& Sons, Ltd, London, p 1.91-206

Vitiello P. Dinet A (1979) Définition et échantillonnage du méiobenthos. Rapp PV Réun Comm Int Explor Scient Mer Méditerr 15/16:279--283

Manuscript first recelved: April 25, 1996

Revised version accepted: March 18, 1997 